\title{
Experimental Investigation of Phytodesalination Rate of Duckweed (Lemna Minor) in Brackish Water
}

\author{
Kiridi, E. A and Zalmon, G. P \\ Department of Agricultural and Environmental Engineering, \\ Niger Delta University, Bayelsa State, Nigeria.
}

\begin{abstract}
Freshwater in most communities along estuaries such as the Niger Delta region of Nigeria is difficult to access as both the surface and groundwater around it has a higher salinity than acceptable standards. Desalination plants are on the other hand, are energy-consuming and costly method to run. The researchers of this paper conducted an experimental investigation on phytodesalination rate of duckweed in brackish water. Approximately $100 \mathrm{~g}$ of morning glory were placed in a plastic trough containing 10 liters of brackish water (salinity 7.69 ppt) in three replicates and studied daily for 6 days. The experiment was conducted to measure the treatment parameters of electrical conductivity (EC), pH, total dissolved solids (TDS) and salinity. Results showed that maximum reductions of most of the water parameters were observed after 3 days of the research. The recorded phytodesalination rates were $+0.072 \mathrm{ppt} / \mathrm{g} /$ day for EC, $+47.8 \mathrm{ppt} / \mathrm{g} /$ day for TDS and $+0.053 \mathrm{ppt} / \mathrm{g} / \mathrm{day}$ for salinity. Also, the percentage reduction for EC, TDS and salinity were $16.4 \%, 16.3 \%$ and $20.7 \%$ respectively. The water hyacinth started showing signs of nutrient starvation and a reduced rate of desalination after 3 days. Analysis of variance show that there was no significant difference between the control and duckweed treatment means at 95 percent confidence level of the water parameters except for EC. This research can be optimized by continuously removing the spent duckweed and re-introducing fresh ones in 3 days intervals until salinity is within the safe threshold.
\end{abstract}

Keywords: Phytodesalination, Duckweed, Salinity, Brackish Water.

\subsection{INTRODUCTION}

Salinity is one of the most important factors affecting agricultural crop production, with adverse effects on germination, plant vigour and crop yields [1]. Salinization mainly affects many irrigated areas because of the use of brackish water. Globally, salt has destroyed over 45 million hectares of irrigated land and 1,5 million hectares are taken out of cultivation each year due to high levels of salinity in the soil [1].

The plants undergo water stress during initial exposure to salinity, which in turn reduces leaf expansion. The osmotic effects of salinity stress can be observed immediately after salt application, resulting in impaired cell expansion and cell division as well as stomatal closure. [2,3]. During long-term exposure to salinity, plants undergo ionic stress, which can lead to premature senescence of adult leaves and thus a reduction in the available photosynthetic area to support continuous growth [4].

Surface water salinization can have many different causes. Irrigation and rising groundwater tables have been identified as one of the main causes of secondary salinization, particularly in the arid and semi-arid region of the world where crop production consumes large amounts of water. Since the crop absorbs only a fraction of the salt in the irrigating water, the salt concentrate soil becomes saltier [5]. These salts may be leached out through runoff and end up in nearby rivers.

In temperate regions of the world, salinization of the stream was frequently reported as a result of the use of salts as a defrosting agent for road use [6,7]. Most of the salts used on the road during rainfall and snow melting times are transferred to adjacent streams [8] and there has not been any conscious effort to reduce this salt loading

Freshwater in most communities along estuaries such as the Niger Delta region of Nigeria is difficult to access as both the surface and groundwater around it has higher salinity than acceptable standards, so desalinating brackish water is necessary so that it can be used for farming practices. Conventional desalination plants are extremely expensive and energy-consuming to operate. The use of aquatic plants for desalination is therefore not only a cheaper, easier-to-operate alternative but also an environmentally friendly option. 
Several researchers reported phytoremediation of various wastewaters $[9,10,11]$. Therefore, the purpose of this research is to measure the salinity level of brackish water as well as the effects of duckweed on brackish water for 6 days in order to evaluate its desalination effectiveness.

\subsection{MATERIALS AND METHODS}

\subsection{Experimental site}

The experimental site was an open space in front of the laboratory of the Department of Agricultural and Environmental Engineering, Niger Delta University, Wilberforce Island, Bayelsa State, Nigeria. Located in the vegetative mangrove swamp area, the University has a tropical climate with two seasons: the wet season from March to October and the dry season from November to April.

\subsection{Experimental apparatus and procedure}

The experimental apparatus consists of a plastic water storage tank, a weighing scale, $1000 \mathrm{ml}$ measuring cylinder, salt meter (KADY Salt meter MT-8071), electric conductivity meter/TDS meter/thermometer (LTLutron YK-22CT) and pH meter (Testo 206-PH3). Brackish water on was obtained from Ozuboko River $\left(4.7715913^{\circ} \mathrm{N}, 7.0427778^{0} \mathrm{E}\right)$ in Abuloma community in Rivers State, Nigeria and transported down to the experimental site. Some of the physico-chemical characteristics of the brackish are presented in Table 1

The experiment was conducted as described by [9]. Appropriate quantities of duckweed (Lemna minor) in their natural habitats were carefully harvested from within and around Amassoma in Southern Ijaw Local Government Area in Bayelsa State. Approximately $100 \mathrm{~g}$ of each aquatic macrophytes were then placed in three replicates of plastic trough containing 10 litres of brackish water and a control, making the stocking density to be $10 \mathrm{~g} / \mathrm{L}$. Each trough was analysed on a 24 hrs interval for 6 days on the desalination abilities of duckweed on the selected water parameters which were salinity, electrical conductivity (EC), $\mathrm{pH}$, total dissolved solids (TDS).

Table 1. Some physico-chemical characteristics of the brackish water

\begin{tabular}{ll}
\hline Parameters & Value \\
\hline $\mathbf{p H}$ & 6.1 \\
\hline Conductivity (S/m) & 13.19 \\
\hline Temperature ( $\left.{ }^{\mathbf{0}} \mathbf{C}\right)$ & 27 \\
\hline T.D.S (ppt) & 8801 \\
\hline Salinity (ppt) & 7.690 \\
\hline
\end{tabular}

\subsection{RESULTS AND DISCUSSIONS}

The duckweed started showing signs of nutrients starvation after day 4 of the research. Table 2 shows that duckweed was able to gradually reduce the concentrations of EC and TDS within the first three days of their introduction, thereafter, an increase in concentration levels were observed which suggests re-introduction of the EC and TDS. Also, there was a steady reductionof the concentration levels of salinity. Figures 1 to 4 show the comparisons of the control and the effects of duckweed with respect to the selected water parameters. The trend shows that with the exception of their effects on salinity, there was an initial gradual reduction of concentration levels for 3 days for $\mathrm{pH}$, EC and TDS, thereafter, a gradual increase. 
International Journal of Advances in Scientific Research and Engineering (ijasre), Vol 6 (2), February-2020

Table 2. Mean effects of the duckweed treatment on some physicochemical characteristics of the brackish water for the 6 days intervals

\begin{tabular}{cccccccc}
\hline \multirow{7}{*}{$\begin{array}{c}\text { Brackish } \\
\text { water } \\
\text { parameters }\end{array}$} & $\mathbf{0}$ & $\mathbf{1}$ & $\mathbf{2}$ & $\mathbf{3}$ & $\mathbf{4}$ & $\mathbf{5}$ & $\mathbf{6}$ \\
\cline { 2 - 8 } & 6.10 & 6.74 & 6.79 & 6.30 & 6.40 & 6.43 & 6.27 \\
\hline $\mathrm{pH}$ & 13.19 & 12.30 & 11.23 & 11.05 & 11.18 & 11.09 & 11.87 \\
\hline EC $(\mathrm{S} / \mathrm{m})$ & 27 & 29.2 & 30 & 26 & 27 & 31 & 30 \\
\hline Temp $\left({ }^{0} \mathrm{C}\right)$ & 8801 & 8187 & 7480 & 7367 & 8653 & 8587 & 7907 \\
\hline TDS $(\mathrm{ppt})$ & 7.69 & 7.2 & 6.31 & 6.10 & 5.35 & 5.24 & 5.34 \\
\hline Salinity $(\mathrm{ppt})$ & & & & & & & \\
\hline
\end{tabular}

Table 3 show the phytodesalination rate of duckweed in brackish water after 3 days of the research. The desalination rates observed were $+0.072 \mathrm{ppt} / \mathrm{g} /$ day for EC, $+47.8 \mathrm{ppt} / \mathrm{g} /$ day for TDS and $+0.053 \mathrm{ppt} / \mathrm{g} /$ day for salinity. A summary of the analysis of variance (Anova) between the control and duckweed treatment on the brackish water is shown in Table 4. The result show $\mathrm{F}$ (cal) is less than F (crit) and the $\mathrm{P}$ value is $>0.05$, therefore it can be concluded statistically that there was no significant difference between duckweed treatment and the control except for Electrical conductivity (EC). The P values for TDS and salinity were marginally insignificant and can be attributed to the reversed absorption of some salts from the duckweed to the brackish water on the 3 days of phytodesalination.

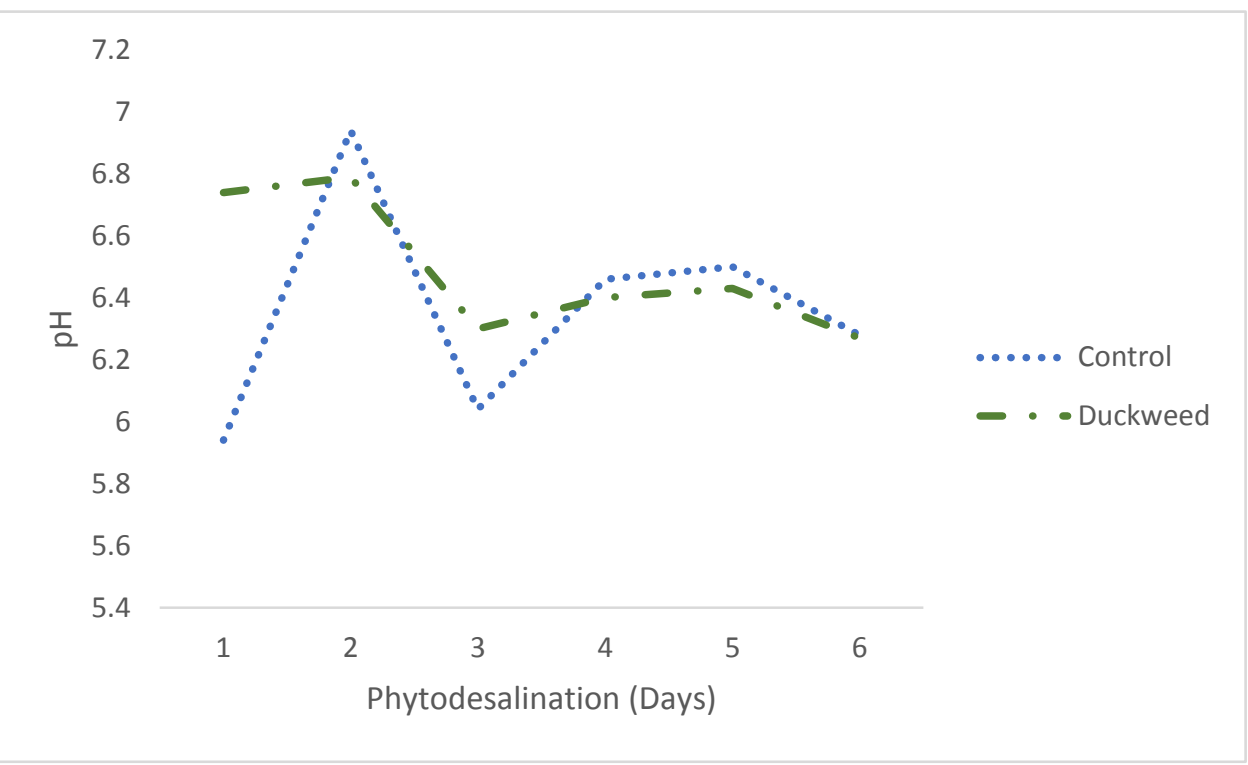

Figure 1. Comparison between control, duckweed treatment means with respect to $\mathrm{pH}$ 
International Journal of Advances in Scientific Research and Engineering (ijasre), Vol 6 (2), February-2020

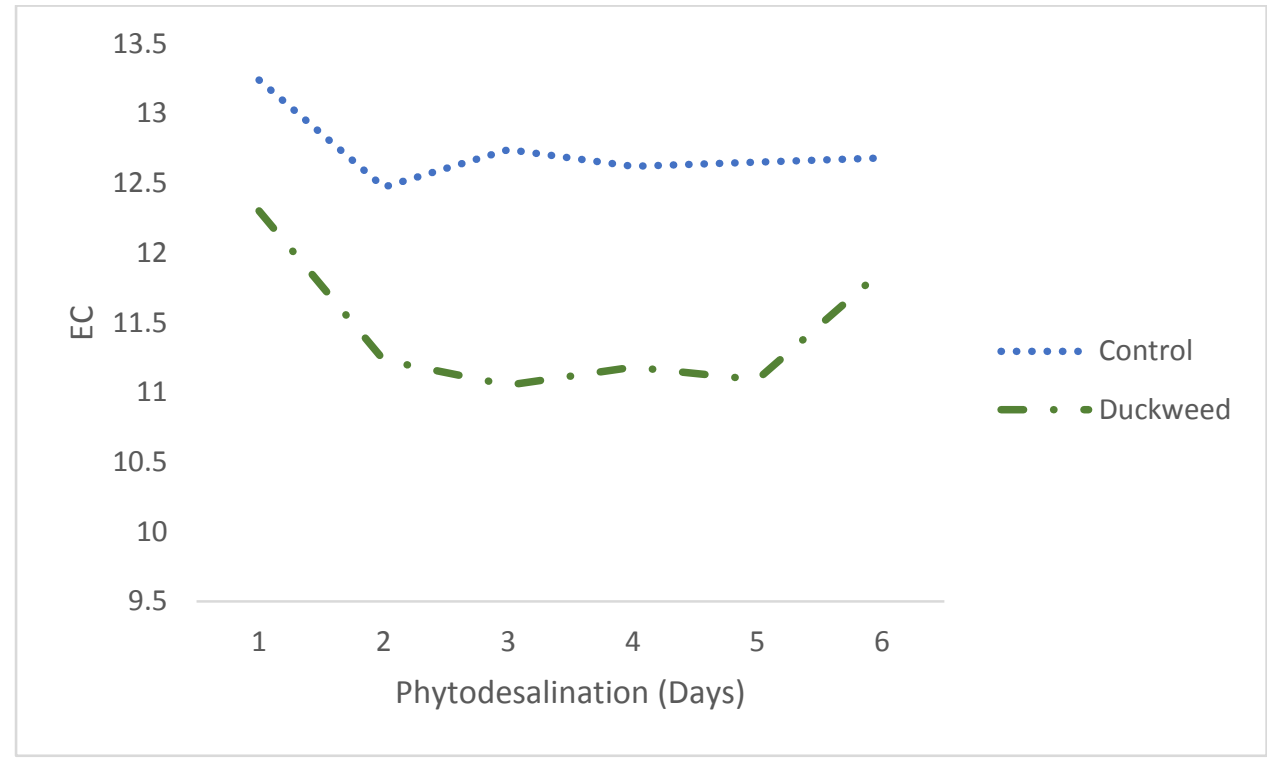

Figure 2. Comparison between control, duckweed treatment means with respect to EC

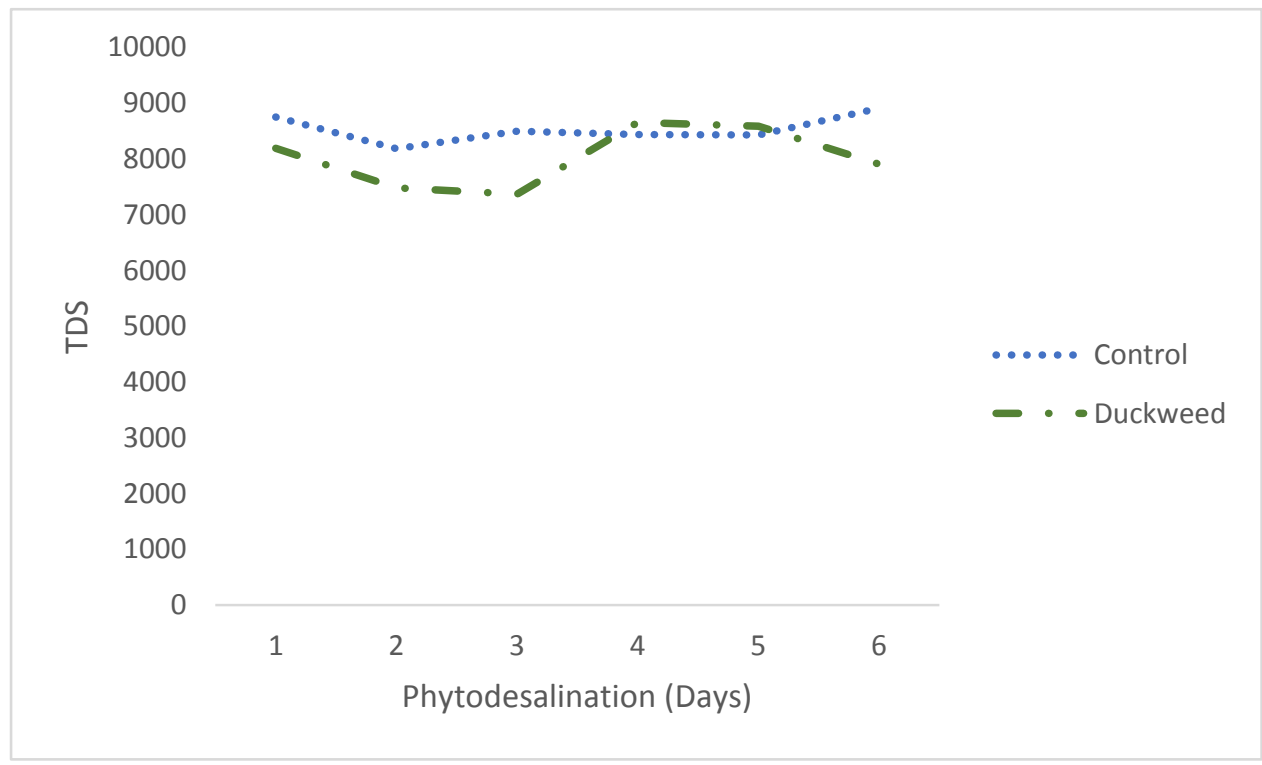

Figure 3. Comparison between control, duckweed treatment means with respect to TDS 
International Journal of Advances in Scientific Research and Engineering (ijasre), Vol 6 (2), February-2020

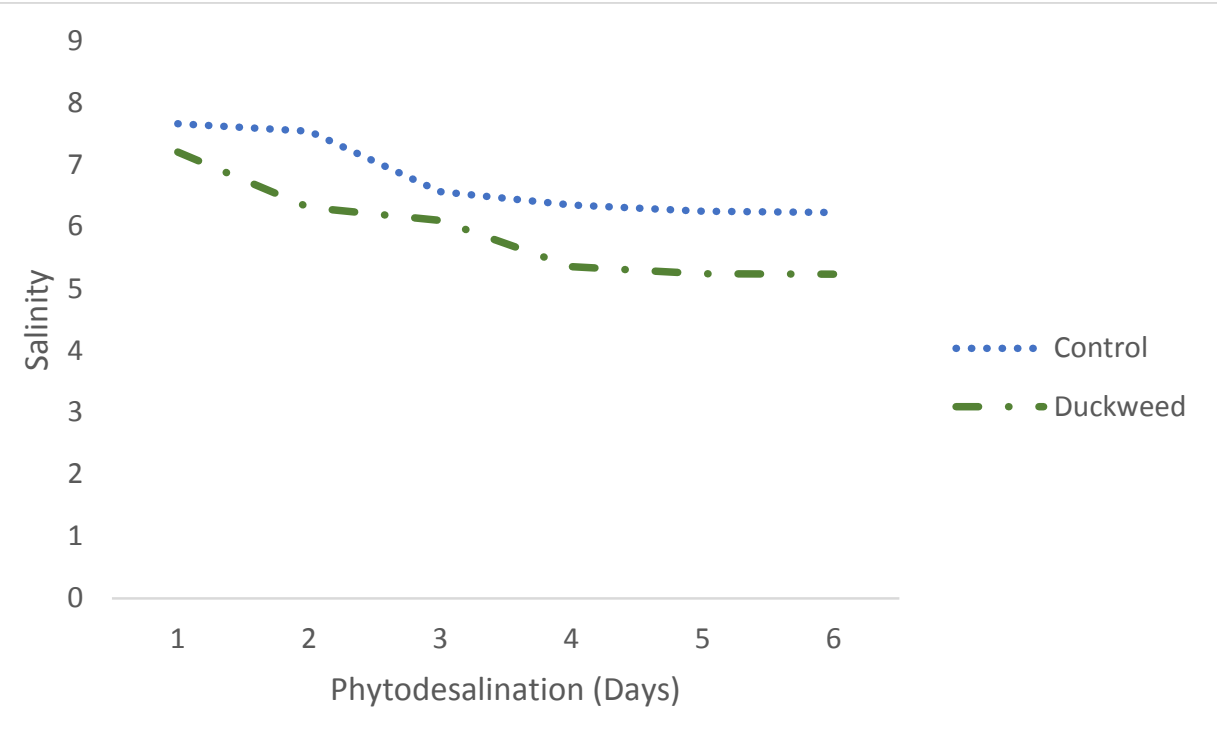

Figure 4. Comparison between control, duckweed treatment means with respect to salinity

Table 3 Phytodesalination rates of duckweed treatment in brackish water after 3 days

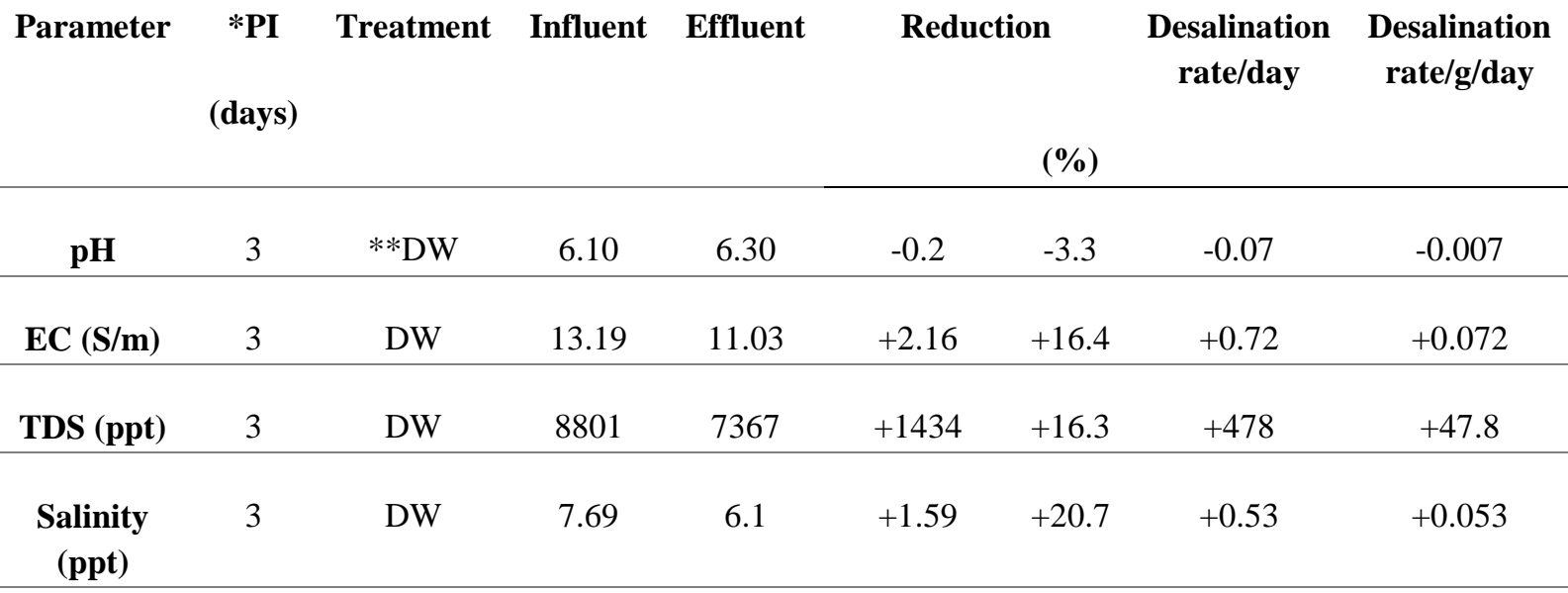

$* \mathrm{PI}=$ Phytodesalination interval $; *$ DW $=$ Duckweed

Table 4: Anova summary between the control and duckweed treatment on the brackish water

\begin{tabular}{ccccccccc}
\hline Parameter & $\begin{array}{c}\text { Control } \\
\text { mean }\end{array}$ & $\begin{array}{c}\text { Treatment } \\
\text { mean }\end{array}$ & $\begin{array}{c}\text { Control } \\
\text { variance }\end{array}$ & $\begin{array}{c}\text { Treatment } \\
\text { variance }\end{array}$ & $\begin{array}{c}\text { F } \\
\text { (Cal) }\end{array}$ & $\begin{array}{c}\text { F } \\
\text { (Crit) }\end{array}$ & $\begin{array}{c}\text { P } \\
\text { (value) }\end{array}$ & $\begin{array}{c}* \text { Treatment } \\
\text { Remarks }\end{array}$ \\
\hline $\mathbf{p H}$ & 6.36 & 6.49 & 0.13024 & 0.049737 & 0.55 & 4.96 & 0.475745 & NS \\
\hline EC(S/m) & 12.73 & 11.45 & 0.069747 & 0.261947 & 29.64 & 4.96 & 0.000283 & S \\
\hline TDS (ppt) & 8531.167 & 8030.167 & 66619.37 & 296045 & 4.15 & 4.96 & 0.068901 & NS \\
\hline $\begin{array}{c}\text { Salinity } \\
\text { (ppt) }\end{array}$ & 6.765 & 5.905 & 0.43347 & 0.61699 & 4.22 & 4.96 & 0.066907 & NS \\
\hline
\end{tabular}

*Treatment Remarks: S = Significant; NS = Not significant 


\subsection{CONCLUSIONS AND RECOMMENDATIONS}

The conclusions of this research are that duckweed was able to reduce the concentration levels of the selected brackish water parameter, the maximum reduction of concentrations of water parameters was on the day 3 of research except for salinity and the concentration levels of the water parameter began to increase after day 3 except for salinity

It is therefore recommended that this research be optimised by removing the duckweed in 3 days intervals to prevent reintroduction of the absorbed salts and fresh ones introduced to continue the phytodesalination process until salinity is within the safe treshold.

This research if optimised, may show that phytodesalination using duckweed is a cheaper alternative and should be employed in design of the desalination of brackish surface water and freshwater stream polluted by the salt used as defroster in the winter months.

\section{REFERENCES}

[1] Munns, R., \& Tester, M. (2008). Mechanisms of salinity tolerance. Annual Review of Plant Biology, 59, 651-681.

[2] Flowers, T. J. (2004). Improving crop salt tolerance. Journal of Experimental Botany, 55(396), 307-319.

[3] Munns, R. (2002). Comparative physiology of salt and water stress. Plant, Cell \& Environment, 25(2), 239-250.

[4] Cramer, G. R., \& Nowak, R. S. (1992). Supplemental manganese improves the relative growth, net assimilation and photosynthetic rates of salt-stressed barley. Physiologia Plantarum, 84(4), 600-605.

[5] Lerotholi, S., Palmer, C. G and Rowntree, K (2004). Bioassessment of a River in a Semi-arid Agricultural Catchment, Eastern Cape In. Proceedings of 2004 Water Institute of South Africa (WISA) Biennial Conference, Cape Town S.A. pp 338-344.

[6] William, D. D, William, N. E, Cao, Y (2000) Road salt contamination of groundwater in major metropolitan area and development of a biological index to monitor its impact. Water Research 34 (1), 127-138.

[7] Ruth, O (2003) The effects of de-icing in Helsinki urban streams, southern Finland. Water Science and Technology, 48 (9), $33-43$.

[8] Environment Canada (2001). Priority substances list assessment report. Road salt. Canadian Environmental Protection Act, 1999. Environment Canada, Health Canada, Minister of Public Works and Government Services 2001, Ottawa, Ontario. (Available from: http://www.ec. gc.ca/Substances/ese/eng/psap/final/roadsalts.cfm).

[9] Kiridi, E. A and Ogunlela, A, O (2016) Modelling phytoremediation rates of aquatic macrophytes in aquaculture effluent. International Journal of Environmental, Chemical, Ecological, Geological and Geophysical Engineering. Vol 10, No 3. pp 332-339.

[10] Snow, A. M and Ghaly, A. E (2008) A comparative study of the purification of aquaculture wastewater using water hyacinth, water lettuce and parrot's feather. American Journal of Applied Sciences. Vol. 5(4): 440-453.

[11] Körner, S., J. E. Vermaat, and S. Veenstra. 2003. The Capacity of Duckweed to Treat Wastewater. J. Environ. Qual. 32:1583 1590. 